フタル酸ジーnーブチルのマウス体内分布と代謝ならびに核酸，蛋白質との相互作用 ${ }^{1)}$

岡田昌二，為政 脩

静岡薬科大学 2 )

\title{
Distribution and Metabolism of Di-(n-butyl)-phthalate in Mice and Its Interaction with Nucleic Acids and Proteins ${ }^{1)}$
}

\author{
Shoji OKada and Osamu Tamemasa \\ Shizuoka College of Pharmacy2)
}

(Received February 20, 1978)

\begin{abstract}
${ }^{14} \mathrm{C}$-labeled dibutyl phthalate (DBP), one of the most widely utilized plasticizers, when administered orally to mice at a dose of $0.94 \mu \mathrm{Ci} / 25 \mu \mathrm{g} / \mathrm{mouse}$, was rapidly metabolized and excreted. The total radioactivity remaining $8 \mathrm{hr}$ after the administration in $10 \mathrm{kinds}$ of the organs or tissues examined was not more than $1 \%$ of the administered activity. One hour after the administration, the highest radioactivity per organ and per wet weight of tissue was detected in the liver $(2.25 \%$ of the administered) and the kidney $(100 \mathrm{dpm} / \mathrm{mg}$ wet tissue), respectively. In these two organs, ${ }^{14} \mathrm{C}-\mathrm{DBP}$ was metabolized to ${ }^{14} \mathrm{C}$-monobutyl phthalate (MBP) and ${ }^{14} \mathrm{C}$-phthalic acid, and the former was the major metabolite. Although DBP and MBP interacted with DNA in vitro, no radioactivity was recovered from the DNA of ${ }^{14} \mathrm{C}$-DBP-treated cells of mouse liver, possibly because ${ }^{14} \mathrm{C}-\mathrm{DBP}$ and its metabolites were hardly transported into the nuclei.
\end{abstract}

Keywords phthalic acid esters; di-(n-butyl)-phthalate, distribution and metabolism of; mono-(n-butyl)-phthalate; phthalic acid; interaction with DNA, RNA and proteins

プラスチック可塑剤として繁用されているフタル酸エステル類 (PAE) は哺乳動物に対する急性毒性が低く,3,4) かつ速かに排泄される4ために安全な物質と考えられてきたが，プラスチック製品の広範囲にわたる利用に伴っ て人体内に掑取される量も増加してお゙り，長期にわたる体内摂取による遺伝的影響，発癌の可能性あるいは胎児 催奇型性等について問題が提起されてきている.4-6)

PAE の生体内代謝に関しては, PAE の中でもっとも使用量の多い di-(2-ethylhexyl)-phthalate (DEHP) に ついてこれまで多く研究されており,4,6-8) 体内で mono-(2-ethylhexyl)-phthalate (MEHP) 等に变化して速かに 排泄されるとされている。一方，DEHP に次いで使用量の多い di-(n-butyl)-phthalate (DBP) については同様 な推定がなされてはいるものの，報告は少ない.99

本研究では，この DBP の ${ }^{14} \mathrm{C}$-標識体についてマウスに経口投与した場合の体内分布と代謝を明らかにすると

1）一部は日本薬学会第 96 年会で発表, 名古屋, 1976 年 4 月.

2) Location: 2-2-1 Oshika, Shizuoka, 422, Japan.

3) F.A. Patty, "Industrial Hygiene and Toxicology," Vol. II, Interscience Publishers, New York, 1967, pp. $1904-1906$.

4) J. Autian, "Environmental Health Perspectives," No. 4, ed. by U.S. Dept. of Health, Education and Welfare, 1973, pp. 3-26; L. Fishbein, P.W. Albro, J. Chromatogr., 70, 365 (1972).

5) H.J. Hugos, FDA By-Lines, 3, 81 (1972).

6) R.K. Bower, S. Haberman, P.D. Minton, J. Pharmacol. Exp. Ther., 171, 314 (1970); A.R. Singh, W.H. Laurence, J. Autian, J. Pharm..Sci., 61, 51 (1972); Y. Yagi, K. Tutikawa, N. Shimoi, Tevatology, 14, 259 (1976).

7) P.W. Albro, R. Thomas, L. Fishbein, J. Chromatogr., 76, 321 (1973); P.W. Albro, R.O. Thomas, Biochem. Biophys. Acta, 306, 380 (1973).

8) J.W. Daniel, H. Bratt, Toxicology, 2, 51 (1974); D.T. Williams, B.J. Blanchfield, Bull. Environ. Contam. Toxicol., 11, 371 (1974); A. Tanaka, T. Adachi, T. Takahashi, T. Yamaha, Toxicology, 4, 253 (1975).

9) D.T. Williams, B.J. Blanchfield, J. Agr. Food Chem., 23, 854 (1975). 
ともに，遗伝的影響，発癌性，催奇型性等に関与すると考吕られるデオキシリボ核酸 (DNA),リボ核酸 (RNA) および蛋白質との相互作用を検討した。 その結果，DBP あるいはその代謝産物は速か排泄されるが，投与 1 時間後に一時的に ${ }^{14} \mathrm{C}-$ 放射活性が他の臟器に比較して多ぐ検出された肝および腎において, DBP は mono- $(n-$ butyl)-phthalate (MBP) およびフタル酸 (PA) に代謝されていることを見出した，一方，DBP，MBP，PAの らち，DBP および MBP は in vitro で DNA と相互作用を示したが，マウス肘の細胞レベルでは DNA との 結合は認められなかった。

\section{実 験 の 部}

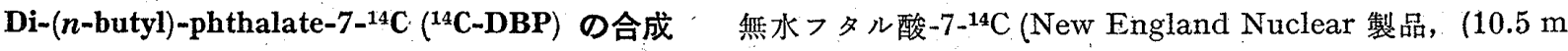
$\mathrm{Ci} / \mathrm{mmol}) 240 \mu \mathrm{Ci}(3.39 \mathrm{mg})$ に $\mathrm{BuOH} 5 \mathrm{ml}$ 抢よび pートルメンスルホン酸 $5 \mathrm{mg}$ を加え; $110^{\circ}, 8$ 特間還流 後反応液を $0.4 \mathrm{M} \mathrm{K}_{2} \mathrm{CO}_{3} 10 \mathrm{ml}$ で 2 回; ついで $\mathrm{H}_{2} \mathrm{O} 10 \mathrm{ml}$ で 1 回洗浄し， $n-\mathrm{BuOH}$ を減圧留去した. 得ら れた反応生成物を $5 \%$-hydrated Florisil (Floridin Co., 100-200×ッシュ) のカラム. $(8 \times 375 \mathrm{~mm}$ ，あらかじ め $n$-hexane $100 \mathrm{ml}$ で洗浄) にのせ, $n$-hexane $50 \mathrm{ml}$ にひきつづき $15 \%$ ether- $n$-hexane $100 \mathrm{ml}$ で溶出し

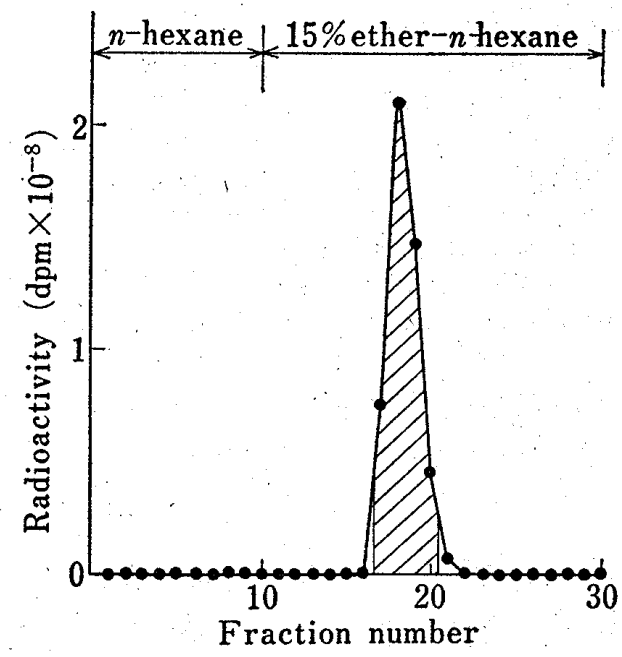

Fig. 1. Chromatographic Separation of ${ }^{14} \mathrm{C}-\mathrm{DBP}$

Column: $5 \%$ hydrated Florisil, 100-200 mesh $8 \times 375 \mathrm{~mm}$.

Fraction: $5 \mathrm{ml}$.

${ }^{14} \mathrm{C}$-DBP was obtained from the shaded portion.
た. 溶出液を $5 \mathrm{ml}$ ずつ分取し，それぞれの放射活性をトルエ ンシンチレーター溶液 ${ }^{10)}$ を用いて液体シンチレーションカウ ンター (Aloka, LSC-602) で測定した. その結果, 生成 ${ }^{14} \mathrm{C}$ DBP は鋭い1 1 ピークとなって現れたので (Fig. 1). 該当フラ クション (No. 17-20) を集め, フード内で溶媒を自然蒸発さ せて ${ }^{14} \mathrm{C}-\mathrm{DBP}$ を得た。 ${ }^{14} \mathrm{C}-\mathrm{DBP}$ の確認は薄層クロマトグラ フィー(TLC) およびラジオガスクロマトグラフィー Aloka, RGC-212) によって行い，それぞれ非放射性既知試料の場所に 1 スポットあるいは1 ピークを得た。放射化学的取量 215 $\mu \mathrm{Ci}$ (収率 $89.6 \%$ ), 化学的収量 $5.7 \mathrm{mg}$ (収率 $89.5 \%$ ), 比放 射能 $10.5 \mathrm{mCi} / \mathrm{mmol}$.

Mono-(n-butyl)-phthalate-7-14C ( $\left.{ }^{14} \mathrm{C}-\mathrm{MBP}\right) \cdot の$ 調製 ${ }^{14} \mathrm{C}$ 標識無水フタル酸と $n-\mathrm{BuOH}$ との反応によって得る常法は微 量の合成には不適当なので, ${ }^{14} \mathrm{C}-\mathrm{DBP}$ の部分加水分解によっ て調製した。すなわち、 ${ }^{14} \mathrm{C}-\mathrm{DBP} 5 \mu \mathrm{Ci}(0.13 \mathrm{mg})$ に $1 \mathrm{~N}$ $\mathrm{NaOH} 100 \mathrm{ml}$ を加え, $37^{\circ}, 1$ 特間振とうし, $1 \mathrm{~N} \mathrm{HCl} \mathrm{で} \mathrm{pH}$ 3 にした後反応生成物を ether $100 \mathrm{ml}$ で 4 回抽出した。 ether 層を $\mathrm{Na}_{2} \mathrm{SO}_{4}$ で脱水後減圧濃縮し, 濃縮液をシリカゲル薄層 (Merck, Kieselguhr F-254, 20×20 cm) に線状にスポットし $\tau$ benzene-dioxane-AcOH $(90: 25: 4)$ で $4^{\circ}, 2$ 時間展開し た.この TLC 上の ${ }^{14} \mathrm{C}-\mathrm{MBP}$ スポット $(R f=0.56)$ をオート ラジオグラフィーで検出し，これをかきとって ether で抽出 乙, 減圧乾燥して ${ }^{14} \mathrm{C}-\mathrm{MBP}$ を得た. 放射化学的収量 $1.06 \mu \mathrm{Ci}$ (収率 $21.2 \%$ ).

Phthalic acid-7-14C ( $\left.{ }^{14} \mathrm{C}-\mathrm{PA}\right)$ の調製 無水フタル酸-7- ${ }^{14} \mathrm{C} に \mathrm{H}_{2} \mathrm{O}$ 加えて ${ }^{14} \mathrm{C}-\mathrm{PA}$ 水溶液とした。

${ }^{14} \mathrm{C}-\mathrm{DBP}$ のマウスへの投与と体内分布の測定 ${ }^{14} \mathrm{C}-\mathrm{DBP}$ ※.5\% カルボキシメチルセルロース (Merck)

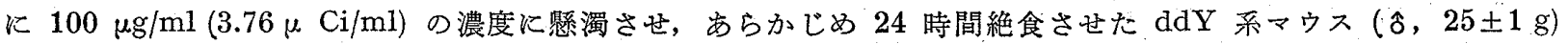
に $0.25 \mathrm{ml}(0.94 \mu \mathrm{Ci} / 25 \mu \mathrm{g} / \mathrm{mouse})$ ずつ胃ゾンデを用いて投与した。投与後 $1,2,4,8,24$ 時間目にそれぞれの マウスを殺して肝, 腎, 脾, 膵, 肺, 横隔膜, 啈丸, 脳, 脂肪体および血液11)をとり出した。各組織 $50 \mathrm{mg}$ Soluene 350 (Packard Instrument Co.) $1 \mathrm{ml}$ を加光，50 に加温して組織を溶解させ，さらに AcOHで中和し た後,トルエンシンチレーター溶液 $10 \mathrm{ml}$ を加えて液体シンチレーションカゥンター-(Aloka, LSC-602) で放射 活性を測定した.

肝および腎組織からの ${ }^{14} \mathrm{C}-\mathrm{DBP}$ 代謝物の抽出と同定 凍結乾燥した肝または腎組織の一定量に少量の ether を加え, テフロンホモジナイザー中で磨砕した後, 加えた ether とともに Soxhlet 抽出器 (東洋沪紙 No. 84 円筒沪紙を使用）に移して Chart 1 に示す抽出操作を行った。

10) 2,5-Diphenyloxazole (DPO) $4 \mathrm{~g}$ おょび 1,4-bis-2-(5-phenyloxazolyl)-benzene (POPOP) $0.1 \mathrm{~g}$ を toluene 11. 飞溶解したもの.

11）血液は眼窝静脈より採取し，直ちに血液凝固阻止剂（シェウ酸アンモニウム $1.2 \mathrm{~g}$ 拉よびシュウ酸カリウ 厶 $0.8 \mathrm{~g}$ を水 $100 \mathrm{ml}$ に溶解) を血液 9 容に対して 1 容加え, その $50 \mathrm{mg}$ を液体シンチレーション用バ イアル中に科取し, $\mathrm{H}_{2} \mathrm{O}_{2}$ 水 $2-3$ 滴を加えて加温脱色後さらに加温して $\mathrm{H}_{2} \mathrm{O}_{2}$ を除いた。 


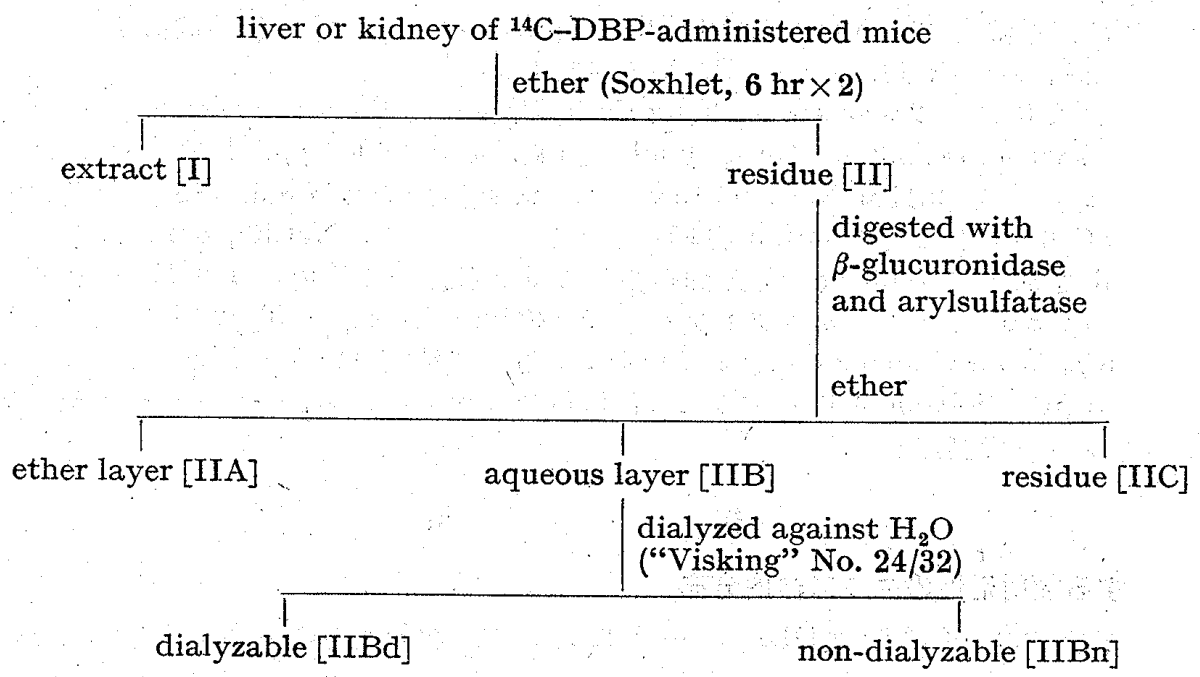

Chart 1. Extraction and Separation of ${ }^{14} \mathrm{C}-\mathrm{DBP}$ and Its Metabolites

代謝物の同定は，シリカゲル薄層 (Merck, Kieselguhr F-254) で benzene-dioxane-AcOH (90:25:4), 95\% EtOH-25\% アンモ二ア水 $(100: 16)$ たは， $n-\mathrm{BuOH}-\mathrm{AcOH}-\mathrm{H}_{2} \mathrm{O}(4: 1: 2)$ を用いて二次元 TLC を行い， オートラジオグラフィーによって放射性スポットの位置を確認し, 標準試料と比較して行った.さらに, さの放 射性スポットをかきとって代謝物を抽出し，これに非放射性標準試料を加えて再結晶を行い，再結晶の前後に捛 ける比放射能が変化しないことを確めて同定を確実にした。

代謝物の $\beta$-グルクロニダーゼおよびアリルスルフアターゼ処理 ether 不溶物中のグルクロン酸抱合体括よ

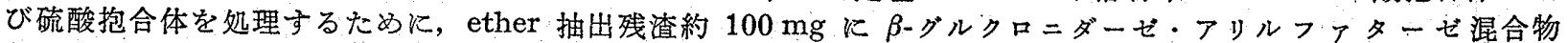
(カタッムリ, Boehringer Mannheim GmbH, $\beta$-グルクロニダーゼ活性 $5.2 \mathrm{U} / \mathrm{ml}$, アリルスルフフターゼ活性

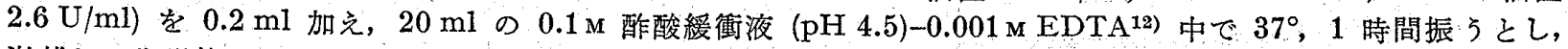
遊離した代謝物を ether 特よび $\mathrm{H}_{2} \mathrm{O}$ で抽出した。

DNA, RNA および蛋白質との結合の測定 DNA（コウシ胸腺, Sigma, Type I, “highly polymerized”), RNA（ラット肝から熱フエノール・SDS ${ }^{12}$ ) 法で抽出 ${ }^{13)}$ )，フルブミン (人血清, Nutritional Biochem. Corp.) およびヒストン（本研究室五島廉輔氏より分与された Ehrlich 腹水癌細胞からの標本）の存在によるDBP

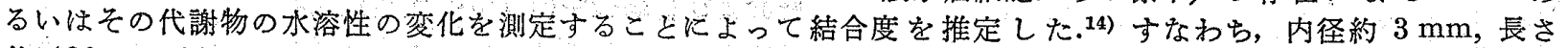
約 $120 \mathrm{~mm}$ (内容量約 $0.85 \mathrm{~cm}^{3}$ ) の上く洗浄した肉厚ガラス管の一端をやや引きのばして封じ，この中に ${ }^{14} \mathrm{C}$ -

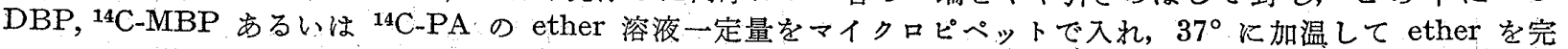
全に除いた後, DNA 等の溶液 $\left(0.01 \mathrm{M} \mathrm{NaCl}-0.01 \mathrm{M}\right.$ Tris $\left.\left.{ }^{12}\right)-\mathrm{HCl}, \mathrm{pH} 7.4\right) 0.1 \mathrm{ml}$ を加えて封管し, $37^{\circ} て ゙ 20$ 特間横位置で振とうした。これを $3000 \mathrm{rpm}, 5$ 分間遠心して ${ }^{14} \mathrm{C}-\mathrm{DBP}$ 等の不溶分を細くなっている側の底部に 集め, 上部を開管して上清 $0.05 \mathrm{ml}$ をとり，セロソルブシンチレーター溶液 ${ }^{15)}$ を加えて液体シンチレーション カウンターで放射活性を測定した。この放射活性值を $0.01 \mathrm{M} \mathrm{NaCl}-0.01 \mathrm{~m}$ Tris-HCl (pH 7.4) のみを加えた対照 実験における值と比較して ${ }^{14} \mathrm{C}-\mathrm{DBP}$ 等の溶解度の増加分を算出した。

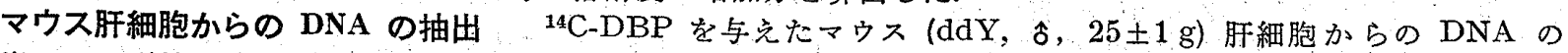

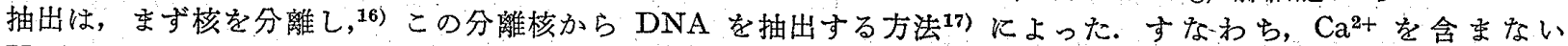
Krebs-Ringer リン酸緩衝液 $\left(\mathrm{Ca}^{2+} \text {-free } \mathrm{KRP}\right)^{18)}$ で灌流, 洗浄後ステンレスふるい(60メッシュ)を通した肝

12) EDTA-ethylenediamine tetraacetic acid, SDS-sodium dodecylsulfate, Tris-tris-(hydroxymethyl)aminomethane.

13) C.M. Mauritzen, Y.C. Choi, H. Busch, "Methods in Cancer Research," Vol. 6, ed. by H. Busch, Academic Press, New York, 1971, pp. 253-282; S. Okada, H. Busch, Cancer Res., 321737 (1972).

14) E. Boyland, B. Green, Brit. J. Cancer, 16, 507 (1962); Idem, Biochem. J., 87, 14p (1963); E. Boyland, Brit. Med. Bull., 20, 121 (1964).

15) DPO $5 \mathrm{~g}$, POPOP $0.5 \mathrm{~g}$ およ゙ naphthalene $80 \mathrm{~g}$ を methylcellosolve $428 \mathrm{ml}$, dioxane $428 \mathrm{ml}$ および toluene $140 \mathrm{ml}$ 飞溶解したもの.

16）村松正突，“生化学実験講坐，2巻，核酸の化学 I,” 日本生化学会編，東京化学同人，東京，1975, pp.76 -77 .

17) J.Marmur, J.Mol. Biol., 3, 280. (1961); 村松正実, “生化学実験講座, 2 巻, 核酸の化学 I, 日本生化学 会編, 東京化学同人, 東京, 1975 , pp. $78-80$.

18) $0.122 \mathrm{M} \mathrm{NaCl}-0.013 \mathrm{M} \mathrm{KCl}-0.65 \mathrm{mM} \mathrm{MgSO}_{4}-0.01 \mathrm{M}$ リン酸緩衝液, $\mathrm{pH} 7.2$. 
組織の $\mathrm{Ca}^{2+}$-free KRP 浮游液 $(2 \mathrm{~g} / 5 \mathrm{ml})$ k ${ }^{14} \mathrm{C}-\mathrm{DBP} 1 \mu \mathrm{Ci}$ を加えて $37^{\circ}, 1$ 時間振と $う し, \mathrm{Ca}^{2+}$-free $\mathrm{KRP}$ で十分洗浄して得た肝組織から下記のように DNA を抽出した。

まず，この肝組織に 2 倍量の $2 \mathrm{M}$ sucrose-3.3 mM CaCl 2 を加えてテフロソホモ.ジナイザーで処理し，ガーゼ ろ過して得た細胞に $2 \mathrm{M}$ sucrose-3.3 $\mathrm{mM} \mathrm{CaCl} 230 \mathrm{ml}$ を加え，40で $6000 \times \boldsymbol{g}, 1$ 時間遠心して核ぺットを得

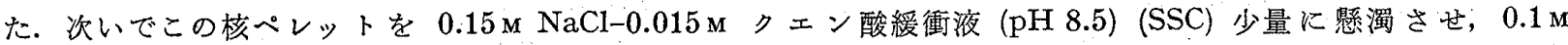
EDTA-2\% SDS-SSC $6 \mathrm{ml}$ を加えて $60^{\circ}, 5$ 分間振と alcohol (25:1) $12 \mathrm{ml}$ を加えて $7000 \times g, 5$ 分間遠心して得た水層に 2 倍量の EtOHを加えてDNAを沈殿 させた。この DNA の SSC 溶液をりボヌクレアーゼ A $(20 \mu \mathrm{g} / \mathrm{ml})$ および $T_{1}(20 \mathrm{U} / \mathrm{ml})$ で処理して混在 RNA を除き，さらに $\mathrm{CHCl}_{3}$-isoamyl alcohol による抽出をくり返して精製 DNA を得た。この DNA 中の ${ }^{14} \mathrm{C}-\mathrm{DBP}$. 由来の放射活性は，試料に Soluene 350 を加えて加温溶解後セロソルブシンチレーター溶液を加えて液体シンチ レーターションカウンターで測定した。

結 果

\section{${ }^{14}$ C-DPB に由来する放射活性のマウス体内分布}

${ }^{14} \mathrm{C}-\mathrm{DBP}$ の経口投与 $(0.94 \mu \mathrm{Ci} / 25 \mu \mathrm{g} \mathrm{DBP} / \mathrm{mouse})$ による ${ }^{14} \mathrm{C}$-放射活性のマウス体内分布とその時間経過にる

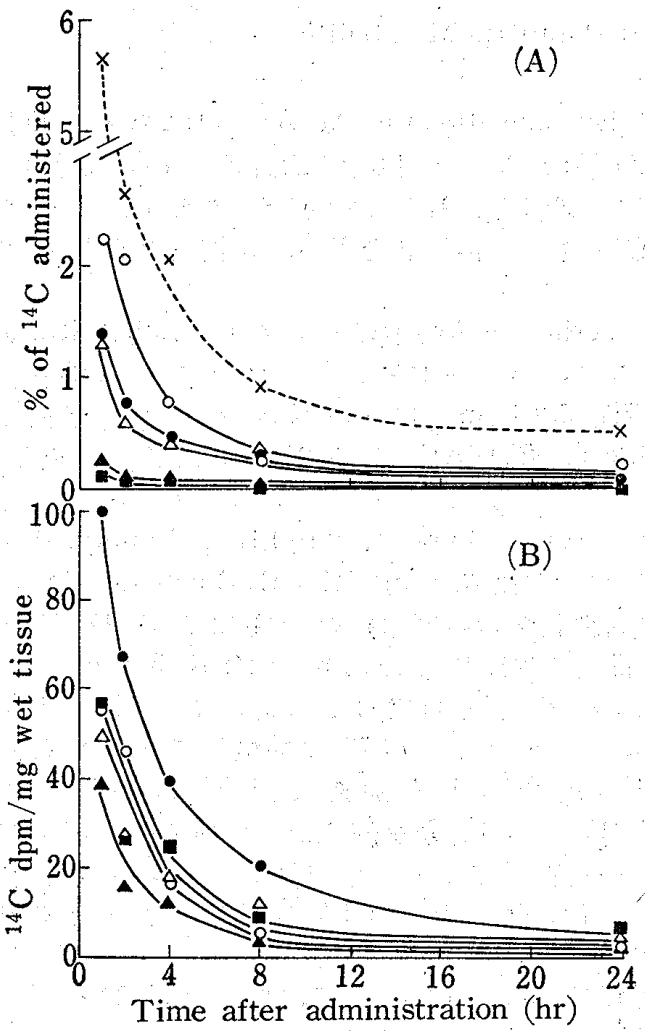

Fig. 2. ${ }^{14} \mathrm{C}$-Distribution in the Organs and Tissues of ${ }^{14} \mathrm{C}$-DBP-Administered Mice

${ }^{14} \mathrm{C}-\mathrm{DBP}$, emulsified in $0.5 \%$ carboxymethylcellulose solution, was orally administered to mice (ddY, $\hat{\delta}, 25 \pm$ $1 \mathrm{~g}, 3$ mice/group) at a dose of $0.94 \mu \mathrm{Ci} / 25 \mu \mathrm{g} /$ mouse. The radioactivity distributed in the organs or tissues, i.e., liver, kidney, spleen, pancreas, lung, brain, testicle, diaphragm, epididymal adipose and blood, was deter mined in a liquid scintillation spectrometer with an aid of Soluene 350. The data shown are mean values obtained with 3 samples. Because of very low radioactivity in spleen, pancreas, brain, testicle and diaphragm, these data are not shown.

(A): expressed as percentage of ${ }^{14} \mathrm{C}$-radioactivity administered/organ or tissue.

(B): expressed as ${ }^{14} \mathrm{C} \mathrm{dpm} / \mathrm{mg}$ wet tissue.

$\times \cdots$ total radioactivity distributed in 10 kinds of organs or tissues tested. $\mathrm{O}$ - liver, - kidney, $\triangle$ - blood, $\Delta$ - lung, - epididymal adipose.
る変化を Fig. 2. に示す. Fig. 2(A) にみられるように，投 与 1 時間後に肝, 腎, 血液, 肺, 脂肪体, 脾, 膵, 辠丸, 横 隔膜および脳中に残存した ${ }^{14} \mathrm{C}$-放射活性の合計值は投与量の $5.7 \%$ に過ぎず，乙かもその後の時間経過とともに急激に減 少して, 投与 8 時間後には $0.9 \%$ となった.この放射活性 を各藏器, 組織について比較すると肝にもっとも高く, 腎,

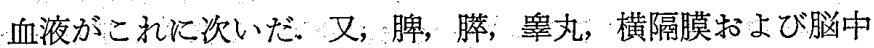
の分布はきわめて少なく，ほとんど検出できなかった。

一方, 各臓器, 組織の単位湿重量当りの放射活性は, Fig. 2 (B) に示すように堅にもっとも高く, 脂肪体, 血液扣よび 肝がこれに次いだ。な拉，脾，膵，辠丸，横隔膜和よび脳中 の比放射活性はいずれも図示困難な程度に低かった。

\section{肝および腎組織中の DBP 代謝生成物}

臓器全体の放射活性あるいは単位湿重量当りの比放射活性 がもっとも高かった肝执よび腎組織（Fig. 2) について，投 与 1 時間後に拈许る ${ }^{14}$ C-DBP からの代謝生成物をしらべ た.

Table I に示すように，両組織とも ${ }^{14} \mathrm{C}$-放射活性の 56 $59 \%$ は直接 ether で抽出可能な形で存在していた (Fraction [I]). さらに, 二次元 TLC に上って分離した後, 各ス ポットの放射活性を測定した結果, Table II に示すように, Fraction [I] の放射活性の大部分は ${ }^{14} \mathrm{C}-\mathrm{MBP}$ によるもので あった.このことはこの画分に非放射性 MBPを加えて再 結晶したとき，再結晶の前後で比放射能がほとんど変化しな いことからも確かめられた (Table III).

Ether 抽出残稙については, 肝, 腎亡も文 $\beta$-グルクロ= ダーゼ打よびアリルスルファターゼ処理後の水溶性画分に もっとも高い放射活性が認められた。この放射活性の汪とん， ぞは透析によって外液に検出され (Table I), TLC (Table II) 物よび再結晶法 (Table III) によって大部分が ${ }^{14} \mathrm{C}-\mathrm{PA}$ によるものであることが示された。

以上の結果から，経口投与時に DBP，は速かに代謝され， 
TABLE I. ${ }^{14} \mathrm{C}-$ Radioactivity Fractionated from Liver and Kidney of ${ }^{14} \mathrm{C}$-DBP-Administered Mice ${ }^{\left.a_{1}\right)}$

\begin{tabular}{|c|c|c|c|}
\hline & \multirow{2}{*}{ Fraction } & \multicolumn{2}{|c|}{$\%$ radioactivity of organ } \\
\hline & & Liver. & Kidney \\
\hline \multicolumn{4}{|c|}{ Extracted with ether } \\
\hline & {$[\mathbf{I}]$ extract } & 58.7 & 56.8 \\
\hline & [II] residue & 34.1 & 36.1 \\
\hline & \multicolumn{3}{|c|}{ Fraction $[\mathrm{II}]$, digested with $\beta$-glucuronidase and arylsulfatase } \\
\hline & [IIA] ether extract & 1.6 & 9.6 \\
\hline & [IIB] $\quad \mathrm{H}_{2} \mathrm{O}$-extract & 29.0 & 25.7 \\
\hline 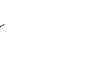 & [IIC] residue & 6.4 & 0.9 \\
\hline & \multicolumn{3}{|l|}{ Fraction[IIB], dialyzed : } \\
\hline & [IIBd] dialyzable & 27.1 & 23.9 \\
\hline & [IIBn] non-dialyzable & 1.0 & 0.7 \\
\hline
\end{tabular}

a) Mice (ddY, $\hat{o}, 25 \pm 1 \mathrm{~g}$ ) were orally given with ${ }^{14} \mathrm{C}-\mathrm{DBP}$ at a dose of $0.94 \mu \mathrm{Ci} / 25 \mu \mathrm{g} /$ mouse and maintained for $1 \mathrm{hr}$.

TABLE II. Contents of ${ }^{14} \mathrm{C}$-Labeled DBP, MBP and PA in the Fractions Obtained from Liver and Kidney of ${ }^{14} \mathrm{C}-\mathrm{DBP}$-Administered Mice

\begin{tabular}{|c|c|c|c|c|c|c|c|c|}
\hline \multirow{3}{*}{ Fraction $a)$} & \multirow{2}{*}{\multicolumn{2}{|c|}{$\begin{array}{c}\text { Solvent system for } \\
2 \text { diniension } \\
\left.\text { TLC }^{b}\right)\end{array}$}} & \multicolumn{5}{|c|}{$\%$ radioactivity of organ } & \multirow[b]{3}{*}{ PA } \\
\hline & & & \multirow[b]{2}{*}{ DBP } & Liver & \multirow[b]{2}{*}{$\mathrm{PA}$} & \multirow{2}{*}{ DBP } & \multirow{2}{*}{$\frac{\text { Kidney }}{\text { MBP }}$} & \\
\hline & $1 \mathrm{st}$ & $2 \mathrm{nd}$ & & $\mathrm{MBP}$ & & & & \\
\hline$[\mathbf{I}]^{c)}$ & A & B & 1.8 & 50.0 & 2.6 & 1.9 & 50.4 & 2.0 \\
\hline [IIA] & A & B & 0.0 & 0.3 & 1.1 & 0.1 & 7.9 & 0.8 \\
\hline$[\mathrm{IIIBd})^{c)}$ & A & C & 0.2 & 0.1 & 25.4 & 0.6 & 0.6 & 22.3 \\
\hline Total & & & 2.0 & 50.4 & 29.1 & 2.6 & 58.9 & 25.1 \\
\hline
\end{tabular}

a) The same fraction as shown in Table I.

b) Plate: Merck Kieselguhr F-254 solvent: $\mathrm{A}-95 \%$ EtOH-NH${ }_{4} \mathrm{OH}$ (100: 16), B-benzene-dioxane-AcOH (90: 25: 4), $\mathrm{C}-n-\mathrm{BuOH}-\mathrm{AcOH}-\mathrm{H}_{2} \mathrm{O}(4: 1: 2)$.

c) MBP and/or PA contents in the fraction[I] and [IIBd] were also determined by the recrystallization method (Table III).

TABLE III. Contents of MBP or PA in the Ether-Soluble and Water-Soluble Fractions Determined by the Recrystallization Method

\begin{tabular}{|c|c|c|c|c|c|}
\hline \multirow{2}{*}{ Fraction $^{a)}$} & \multirow{2}{*}{ Tissue } & \multirow{2}{*}{$\begin{array}{l}\text { Recryst. } \\
\text { with }^{b)}\end{array}$} & \multicolumn{2}{|c|}{$\begin{array}{c}\text { Specific radioactivity } \\
(\mathrm{dpm} / \mathrm{mg})\end{array}$} & \multirow{2}{*}{ 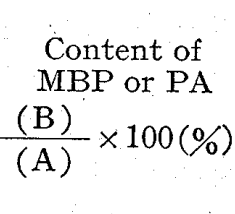 } \\
\hline & & & $\begin{array}{l}\text { Before } \\
\text { recryst. } \\
\text { (A) }\end{array}$ & $\begin{array}{c}\text { After } \\
\text { recryst. } \\
(\mathrm{B})\end{array}$ & \\
\hline$[\mathrm{I}]$ & $\begin{array}{l}\text { Liver } \\
\text { Kidney }\end{array}$ & $\begin{array}{l}\text { MBP } \\
\text { MBP }\end{array}$ & $\begin{array}{r}9592 \\
12370\end{array}$ & $\begin{array}{r}9423 \\
12050\end{array}$ & $\begin{array}{l}\text { MBP } 98.2 \\
\text { MBP } 97.4\end{array}$ \\
\hline [IIBd] & $\begin{array}{l}\text { Liver } \\
\text { Kidney }\end{array}$ & $\begin{array}{l}\text { MBP } \\
\text { PA } \\
\text { MBP } \\
\text { PA }\end{array}$ & $\begin{array}{l}6007 \\
8763 \\
4050 \\
6492\end{array}$ & $\begin{array}{r}230 \\
7832 \\
233 \\
6266\end{array}$ & $\begin{array}{lr}\text { MBP } & 3.8 \\
\text { PA } & 89.4 \\
\text { MBP } & 5.8 \\
\text { PA } & 96.5\end{array}$ \\
\hline
\end{tabular}

a). The same fraction as shown in Table $I$ and II.

b) Solvent for the recrystallization: MBP $-n$-hexane-benzene (3:1), $\mathrm{PA}-\mathrm{H}_{2} \mathrm{O}$. 
TABLE IV. Solubility of DBP, MBP and PA in Bio-Macromolecule Solution

\begin{tabular}{llll}
\hline Solution & $(5)$ & \multicolumn{3}{c}{ Solubility at $37^{\circ}(\mathrm{mg} / 100 \mathrm{ml})^{b)}$} \\
& DBP & MBP & PA \\
\hline Control & $1.3 \pm 0.1$ & $306 \pm 15$ & $6863 \pm 142$ \\
DNA & $5.2 \pm 0.8^{c)}$ & $415 \pm 26^{c)}$ & $7081 \pm 160$ \\
RNA & $1.1 \pm 0.1$ & $376 \pm 9^{c)}$ & $6873 \pm 173$ \\
Albumin & $2.9 \pm 0.3^{c)}$ & $289 \pm 24$ & $6909 \pm 114$ \\
Histone & $2.8 \pm 0.3^{c)}$ & $287 \pm 25$ & $7164 \pm 243$ \\
\hline
\end{tabular}

a) In 0.01 м $\mathrm{NaCl}-0.01$ м Tris-HCl, $\mathrm{pH} 7.4$.

b) Mean \pm S.E. $(n=3)$.

c) Significant $(p<0.01)$.

投与 1 時間後には肝特よび腎には DBP 自身はほとんど存在せず, $50-60 \%$ が MBP に，25一30\%が PA に変化していることが明らかになった (Table II).

\section{DBP, MBP および PA の核酸ならびに蛋白質との相互作用}

Fig. 2 および Table I一III に示したよりに，マウスに経口投与された DBP は速かに MBP 謝されるとともに排泄されるが，一方では多量に与えた場合の胎児催奇型性あるいは変異原性も指摘されて拉 り,4,6) 従ってたとえ少量であっても核酸あるいは蛋白質と結合した場合に問題がおこり得ると考えられる.そこ

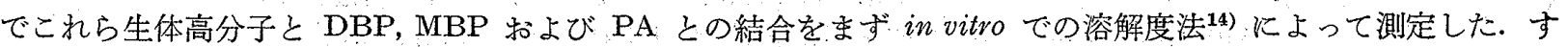
なわち， ${ }^{14} \mathrm{C}$-標識 $\mathrm{DBP}, \mathrm{MBP}$ なな 度がコウシ胸腺 DNA, ラット肝 RNA, 人血清アルブミンあるいは Ehrlich 腹水癌細胞七ストンの存在 $(3 \mathrm{mg} /$ ml) で増大するかどうかをしらべた。

その結果, Table IV に示すように, DNA は DBP および MBP の水に対する溶解度を明らかに増加させた。

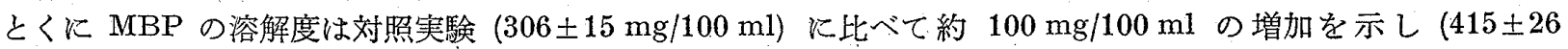
$\mathrm{mg} / 100 \mathrm{ml}), \mathrm{DNA}$ との間にかなりの相互作用を和こすことが推定された，MBP D DBP と異なり，RNA 溶 液中でも明らかな溶解度の増大 (約 $70 \mathrm{mg} / 100 \mathrm{ml}$ ) がみら， RNA との間にも相互作用が存在することが推測 された。一方 $\mathrm{DBP}$ はアルブミンおよびヒストンの存在で溶解度がやや增大したが，MBP ではこのような現象 はみられなからた。 また，PA に関してはいずれの場合も明らかな溶解度変化はみられなかった。な和，予備実 験に㻑てて $\mathrm{pH}$ 6.5-8.0 の間での DBP, MBP 和よび PA の水に対する溶解度の有意義はみられなかったので, 上記の溶解度変化は明らかに DNA 等の存在によるものである.

DBP 和よび MBP が in vitro で DNA と相互作用を示すことから, 次に細胞レベルでの DNA との結合を

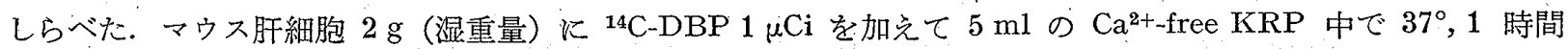
振とうしたものからDNA を抽出し，その放射活性を対照実験（ ${ }^{19} \mathrm{C}-\mathrm{DBP}$ を加えずに肝細胞を同様に保温振と らした後に ${ }^{14} \mathrm{C}-\mathrm{DBP} 1 \mu \mathrm{Ci}$ を加え, 直ちに氷冷洗浄して DNA を抽出) の值と比較した. その結果, DNA 中 には放射活性は全く認められなかった。

考 察

PAE の中でもっとも多用されているDEHP は, ラットへの経口投与時にすず脺りパーゼによる加水分解を 受けて mono-(2-ethylhexyl)-phthalate (MEHP) となり，さらに 分解され，いずれも速かに排泄されることが知られている.7) 本研究に拉いて DBP のマウスへの経口投与 1 時 間後にすでに肝および腎から DBP に代って MBP と PA が多量に検出された（Table II，III) とは，DBP についても DEHP と同様な代謝経路が存在することを示咬している。両組織に和いて，MBP 特よび PA とし て得られた放射活性值は組織内全放射活性の 50-60\% (MBP) 叔よび $25-30 \%$ (PA) に相当し，両者の合計は 80-84\% に達した (Table II). 笑験操作上の多少の損失によって回収率は $100 \%$ に満たないと予想されるので, MBP と PA 以外の安定な代謝生成物はほとんど存在しないものと考えられる.

MBP の大部分は遊離の状態で存在するが, 腎組織中では一部, すなわち組織内全放射活性の7.9\%に相当す 
る部分が $\beta$ ダルクロニダーゼ・アリルスルファターゼ処理によってはじめて ether 可溶性になることから (Table II)，この分はグルクロン酸もしくは硫酸抱合体として存在していたと考兄られる.一方，肝ではこのような MBP. の抱合体がほとんど検出されず (Table II)，したがって肝で生成して抱合体が直ちに排泟されるすのと考兄られ る.

DBP 特よび MBP は DNA の存在で水溶性が增加し (Table IV), DNA との相互作用が in vitro では括こ ると推定されたが， ${ }^{14} \mathrm{C}-\mathrm{DBP}$ を与えたマウス肝細胞から抽出した DNA には放射活性が恰出されなかった。こ の場合， DBP の少なくとも一部は細胞内で MBP 飞変化していると考兄られ，19) in vitro での DNA との相互 作用は DBP 上りも MBP の方が大きい (Table IV) にもかかからず，in vivo で結合がみられなかったことに

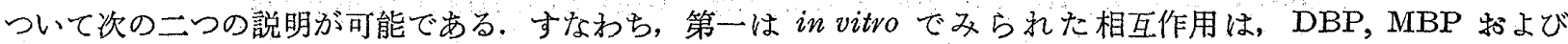
DNA の化学構造から考光て, 共有結合, イオン結合等の強い結合によるものではなく，䋆そらく“stacking” に上る弱いのもであり，したがって細胞内で DNA と相互作用をしていても抽出時海離する場合である. 第二 は DBP あるいは MBP が膜系なぞの脂質に対して親和性が高いために核内の DNA 飞まで到達し得ない場合 である.この二つの可能性のいずれが高いかを本実験から明確にすることは困難であるが，DEHP の場合はウ

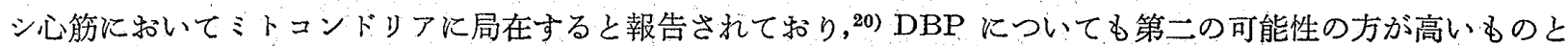
推測される. 一方, DBP 执よび DEHP は $1 \mathrm{mM}$ 以下の低濃度でラット肝ミトコンドリフの呼吸阻害を和こす

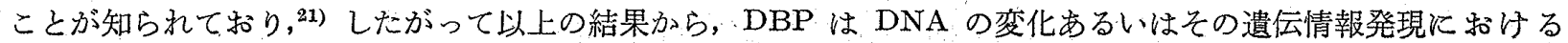

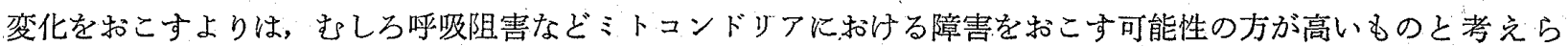
れる。

謝辞 Ehrich 腹水癌細胞ヒストンを分与下さった本研然室 五島廉輔氏ならびに実験の一部に協力いただい た本研究室，手塚雅勝，藤田佳子，加藤久長，加藤葉子の諸氏に感謝する。

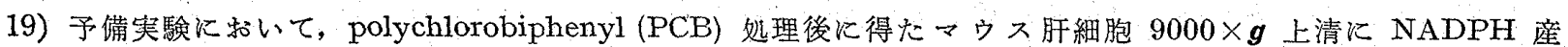

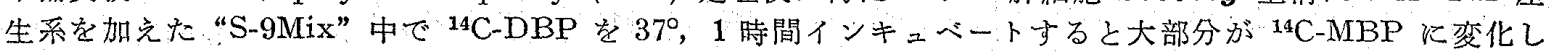
ていた.

20) D.J. Nair, A.P. Alcaraz, B.A. Bier1, M. Beroza, P.P. Nair, Biochemistry, 10, 4228 (1971); D.J. Nair, M. Beroza, P.P. Nair, "Environmental Health Perspectives," No. 3, ed. by U.S. Dept. of Health, Education and Welfare, 1973, pp. 141-148.

21) T. Ohyama, J. Biochem. (Tokyo), 79, 153 (1976); T. Takahashi, Biochem. Pharmacol., 26, 19 (1977). 